\title{
Lateralization of Simulated Sources and Echoes on the Basis of Interaural Differences of Level
}

\author{
Raymond H. Dye Jr \\ Loyola University Chicago, rdye@luc.edu \\ Jacquelyn P. Hill \\ Loyola University Chicago \\ Leslie M. Ryan \\ Loyola University Chicago \\ Alexander E. Cupler \\ Loyola University Chicago \\ Kevin M. Bannon \\ Loyola University Chicago \\ Follow this and additional works at: https://ecommons.luc.edu/psychology_facpubs \\ Part of the Psychology Commons
}

\section{Recommended Citation}

Dye, Raymond H. Jr; Hill, Jacquelyn P.; Ryan, Leslie M.; Cupler, Alexander E.; and Bannon, Kevin M.. Lateralization of Simulated Sources and Echoes on the Basis of Interaural Differences of Level. Journal of the Acoustical Society of America, 134, : 2013. Retrieved from Loyola eCommons, Psychology: Faculty Publications and Other Works, http://dx.doi.org/10.1121/1.4831384

This Presentation is brought to you for free and open access by the Faculty Publications and Other Works by Department at Loyola eCommons. It has been accepted for inclusion in Psychology: Faculty Publications and Other Works by an authorized administrator of Loyola eCommons. For more information, please contact ecommons@luc.edu.

\section{(c) $(\$)$}

This work is licensed under a Creative Commons Attribution-Noncommercial-No Derivative Works 3.0 License. (c) 2013 Acoustical Society of America 


\section{Acoustical Society of America}

\section{The Journal of the Acoustical Society of America}

\section{F Lateralization of simulated sources and echoes on the basis of interaural differences of level}

Raymond H. Dye ${ }^{1}$, Jacquelyn P. Hill' ${ }^{1}$, Leslie M. Ryan ${ }^{1}$, Alexander E. Cupler ${ }^{1}$ and Kevin M. Bannon ${ }^{1}$

+ VIEW AFFiLiations

J. Acoust. Soc. Am. 134, 4194 (Fri Nov 01 00:00:00 UTC 2013);

http://dx.doi.org/10.1121/1.4831384

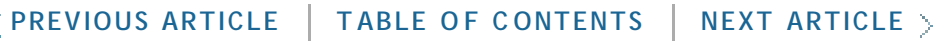

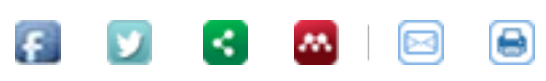

Abstract

This experiment assessed the relative weights given to source and echo pulses lateralized on the basis of interaural differences of level (IDLs). Separate conditions were run in which the to-be-judged target was the first (source) or second (echo) pulse. Each trial consisted of two intervals; the first presented a $3000-\mathrm{Hz}$ diotic pulse that marked the intracranial midline and the pitch of the target frequency. The second presented the sequence of a source followed by an echo. Target frequency was always $3000 \mathrm{~Hz}$, while the non-target pulse was presented at 1500, 3000, or $5000 \mathrm{~Hz}$. Delays between the source and echo were varied from 8 to $128 \mathrm{~ms}$. IDL's were chosen for both pulses from Gaussian distributions with $\mu=0 \mathrm{~dB}$ and $\sigma=4 \mathrm{~dB}$. Dependent variables included normalized target weight, proportion correct, and the proportion of responses predicted from the weights. Although target weight and proportion correct generally increased with increasing non-target frequency and echo delay for both target conditions, the effects were always larger when the echo served as the target. The superiority of performance when judging echoes vs sources will be discussed in terms of recency effects in binaural hearing.

(C) 2013 Acoustical Society of America 


\section{MOST READ THIS MONTH}

洸

\section{MOST CITED THIS MONTH}

Theory of Propagation of Elastic Waves in a Fluid-Saturated Porous Solid. I. Low-Frequency Range M. A. Biot

Transformed Up-Down Methods in Psychoacoustics

H. Levitt

Theory of Propagation of Elastic Waves in a Fluid-Saturated Porous Solid. II. Higher Frequency Range M. A. Biot

\section{Access Key}

F Free Content

S Subscribed Content
OA Open Access Content

$\mathrm{T}$ Free Trial Content

\section{Follow AIPP:}

Terms \& conditions

Advertising

Contacts
Privacy

Help 